\title{
Hypothetical Lung Structure of Brachiosaurus (Dinosauria: Sauropoda) Based on Functional Constraints
}

\author{
Steven F. Perry ${ }^{1}$ \& Christian Reuter $^{1}$
}

With 2 figures

\begin{abstract}
Comparison of avian and crocodylian lung structure suggests a basic archosaurian structural type, consisting of four rows of chambers that radiate independently from an intrapulmonary bronchus. The later structure is cartilage-reinforced cranially. Caudally, the cartilage reinforcement diminishes and the radiating pattern of tubular chambers becomes irregular. The presence of extensive pneumatic spaces in the dorsal vertebrae combined with the extremely large size of Brachiosaurus suggests that the dorsal margin of the lungs was strongly attached to the body wall, thus restricting lung inflation in this region. By analogy with similarly structured testudine lungs, it is highly probable that the ventral part of the very large and cavernous lungs consisted of sac-like chambers, which acted as air reservoirs and also ventilated the gas exchange tissue, which was concentrated dorsally.
\end{abstract}

Key words: Brachiosaurus, crocodile, Aves, turtle, Archosauria, lung, parenchyma.

\section{Zusammenfassung}

Die Strukturen der Vogel- und der Krokodillunge deuten auf einen basalen Bauplan der Archosaurierlunge hin, der aus vier Reihen von Kammern besteht, die von einem intrapulmonalen Bronchus entspringen. Dieser ist cranial knorpelig verstärkt. Caudal vermindert sich die knorpelige Verstärkung und das Verteilungsmuster der Kammern wird ungleichmäßig. Die Anwesenheit von pneumatischen Räumen in den Wirbelkörpern und die extreme Größe von Brachiosaurus deuten daraufhin, daß der dorsale Bereich der Lunge mit der Körperwand verbunden war. Dies schränkte die Belüftung der Lunge in dieser Region ein. In Analogie zu den ähnlich strukturierten Schildkrötenlungen ist es höchst wahrscheinlich, daß der ventrale Teil der sehr großen Lungen aus sackartigen Kammern bestand, die als Luftreservoir dienten und das dorsal liegende Gasaustauschgewebe ventilierten.

Schlüsselwörter: Brachiosaurus, Krokodil, Vogel, Schildkröte, Archosaurier, Lunge, Gasaustauschgewebe.

\section{Introduction}

Since lungs of the sauropod Brachiosaurus (Janensch 1937) and of other non-avian dinosaurs are not fossilized, we must rely on indirect evidence to reconstruct the structure of the respiratory system. The principle of using recent analogues to help reconstruct the soft tissue of fossil organisms was developed and exploited by $\mathrm{Cu}$ vier in the early 1800's and is most explicitly stated in his law of the correlation of parts: "Toute être organisé forme un ensemble ... dont tout les parties se correspondent mutuellment... . Aucune de ses parties ne peut changer sans que les autres changent aussi, et par conséquent chacune d'elles, prise séparément, indique et donne toute les autres." (Cuvier 1812). Recently this principle has returned to vogue (Thomason 1995), and has been applied to the reconstruction of theropod lungs (Perry 1992).

In addition, exceptionally well-preserved theropods, in which the hindgut and the liver can be located, have served to intensify the debate regarding the structure and function of lungs in dinosaurs (Ruben et al. 1997, 1999; Sasso \& Signore 1998). To date, however, fossilized lung tissue has not been found.

Fortunately the phylogenetic position of birds relative to other dinosaurs as well as of crocodylians within the Archosauria is well established (Weishampel et al. 1990). Comparison of crocodylian and avian lung structure, both adult and

\footnotetext{
${ }^{1}$ Institut für Zoologie, Rheinische Friedrich-Wilhelms-Universität Bonn, Poppelsdorfer Schloss, D-53115 Bonn, Germany. E-mail: Perry@uni-bonn.de; Reuter@uni-bonn.de Received March 1999, accepted June 1999
} 
embryonic, reveals a basic archosaurian structural type (Fig. 1), which, when compared with that of testudines and of lepidosaurs can be shown to exhibit apomorphies. Using this basic structural type as a starting point, we can consider the functional constraints likely to have been present in Brachiosaurus as a means of refining this model. The results of this hypothetical construct are presented here together with some physiological implications for the respiratory, cardiovascular and locomotor systems.

\section{Functional anatomy of reptilian lungs}

\section{Comparison of crocodylian and avian lungs}

The lungs of crocodylians and of birds are separated ventrally from the remaining body cavity by a postpulmonary septum (Duncker 1978). The lungs themselves are multichambered (Fig. 1). In the cranial part of the lung, four rows of chambers (dorsal, ventral, medial and lateral), each consisting of four or five chambers, followed caudally by an inconstant number of chambers, all emanating from an unbranched

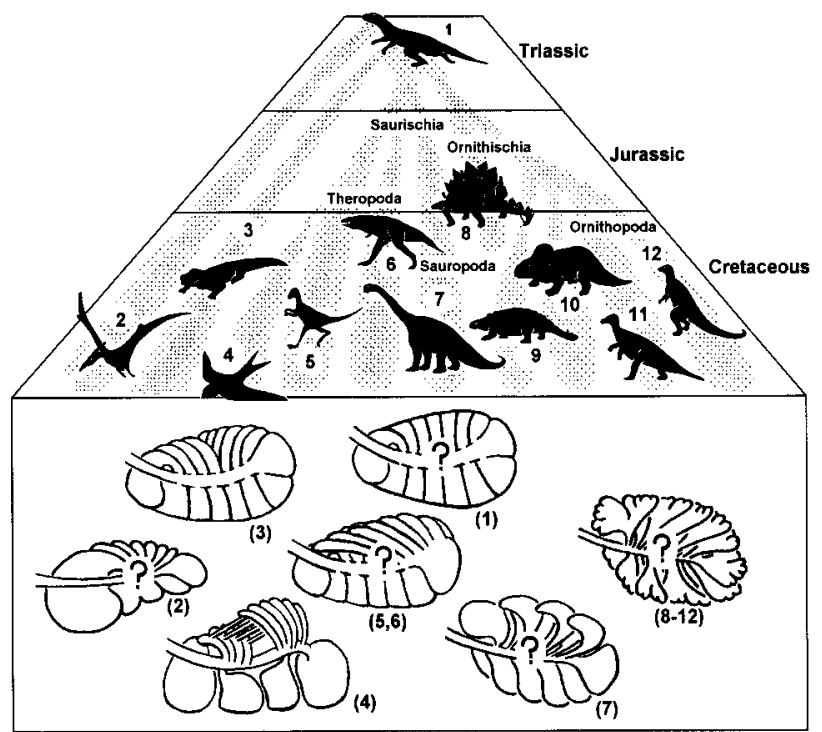

Fig. 1. Simplified representation of possible phylogenetic relationships among major groups of archosaurs. 1, Archosauria (Euparkeria as beginning of line); (1), presumed euparkerian lung type; 2, Pterosauria; (2), presumed avianlike lung with cranial airsacs; 3, Crocodilia; (3), Crocodilian lung type; 4, Aves; (4), Avian lung-airsac system; 5, Coelurosauria (Saurischia: Theropoda); (5), presumed carnosaurian/ early coelurosaurian lung type; 6, Carnosauria (Saurischia: Theropoda), for presumed lung see (5); 7, Sauropoda; (7), presumed multisaccular sauropodian lung type; 8, Stegosauria (Ornitischia); 9, Ankylosauria; 10, Ceratopsia; 11, Hardrosauridae (Ornitischia: Ornithopoda); 12, Iguanodontidae (Ornithischia: Ornithopoda); (8-12), presumed bronchoalveolar-like lung type of Ornitischia (modified after Perry 1989) intrapulmonary bronchus appear to constitute the basic structural type. The medial migration of the intrapulmonary bronchus together with the spiral rotation of the chamber orifices about the intrapulmonary bronchus (proceeding caudad, a right-hand spiral in the left lung, a left-hand spiral in the right lung) modifies the basic plan similarly in both crocodylian and in avian lungs. Notably in the dorsal part of the lung, the chambers are tubular, whereas apically, ventrally and caudally they are saccular. This tendency reaches an extreme in birds, where the tubular chambers form secondary bronchi and the saclike dilatations, the airsacs (Fig. 1). Although testudines and platynotan lizards also possess multichambered lungs, as also must have been the case with ancestral synapsids, the extremely asymmetric (monopodial) branching pattern appears unique to archosaurs.

\section{Lung parenchyma}

The gas exchange tissue, or parenchyma, of reptilian lungs can vary in its depth, in the diameter of the smallest terminal units, and in its distribu-

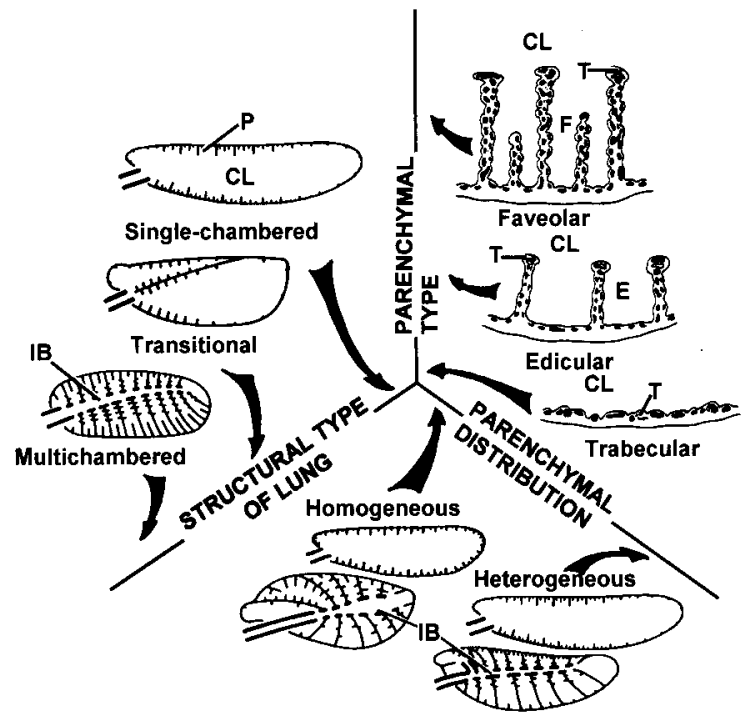

Fig. 2. Schematic representation of three variables in the macroscopic structure of reptilian lungs. Illustrating the structural type of lung are lung schemata of a scincid lizard (single-chambered), an iguanid lizard (transitional) and a sea turtle (multi-chambered); illustrating the parenchymal distribution are lung schemata of a teju lizard (homogeneous, upper) and a caiman (homogeneous, lower), as well as a scincid lizard (heterogeneous, upper) and a varanid lizard (heterogeneous, lower). The various parenchymal types can be found within a single heterogeneously partitioned lung, or they can be characteristic of an entire homogeneously partitioned lung. In general, even within a heterogeneous lung, a particular parenchymal type will predominate. (CL, central lumen of lung or chamber; E, edicula; F, faveolus; IB, intrapulmonary bronchus; $\mathbf{P}$, parenchymal layer; $\mathbf{T}$, smooth-muscular core of trabeculae) 
tion within the lung. Lungs with homogeneously distributed parenchyma (Fig. 2) are intrinsically stable and are often freely suspended in the body cavity. Those with a highly heterogeneous parenchymal distribution, however, are typically firmly attached to the concavity of the body wall. This construction prevents collapse of the densely partitioned dorsal regions. Thus, dorsal attachment is indicative of heterogeneous parenchymal distribution (Fig. 2).

The surface-to-volume ratio in the parenchyma of reptilian lungs is extremely variable, ranging from $18 \mathrm{~cm}^{2} / \mathrm{cm}^{3}$ in the testudine Trachemys scripta to nearly $200 \mathrm{~cm}^{2} / \mathrm{cm}^{3}$ within the singlechambered lungs of scincomorph lizards (Perry 1983). These values compare with $230 \mathrm{~cm}^{2} / \mathrm{cm}^{3}$ for the short-nosed echidna, $750 \mathrm{~cm}^{2} / \mathrm{cm}^{3}$ for the rat and $3000 \mathrm{~cm}^{2} / \mathrm{cm}^{3}$ for the pigeon. Thus, the so-called "septate" lungs of reptiles can achieve surface-to-volume ratios approaching those seen in the alveolar lungs of mammals.

\section{Lung compliance and work of breathing}

Unlike the bronchoalveolar lungs of mammals, reptilian lungs do not possess a system of narrow, branching, nonrespiratory airways. The central lumen of the chamber - the functional equivalent of the airways - in the multichambered lungs (Fig. 2) of the Nile crocodile, for example, accounts for approximately half of the total lung volume. Thus, the resistance to air flow in the airways of reptilian lungs is negligible. The major source of resistance to lung inflation is tissue impedance, the reciprocal of which is "compliance".

In general, compliance - or ease of inflation of the lung - is inversely proportional to the degree of parenchymal partitioning. Since the most densely partitioned parts of heterogeneously partitioned lungs are firmly attached to the body wall and are therefore only capable of limited movement, the lung compliance is determined by the structure of the saclike ventral lung regions.

The physical work of breathing is inversely proportional to compliance. Thus, heterogeneously partitioned, multichambered lungs that are attached to the dorsal body wall represent an advantageous combination of large surface area, low airway resistance and high compliance. The respiratory physiological consequences are the potential for a high rate of gas exchange at low energetic cost.
Reptiles tend to have large lungs, which, like those of mammals, encase the heart and extend from the dorsal arch of the ribs to the sternum. A muscular diaphragm does not develop in the postpulmonary septum of reptiles and the lungs often extend caudally into the pelvic region. Crocodylians represent an exception. In this group, the lungs abut the liver caudally and thus are limited in their caudal extension. They are small relative to the body mass, in keeping with the buoyancy requirements of a diving animal. Inspiration occurs when the liver is pulled caudally by the diaphragmaticus muscle, thus stretching the lungs in the conically broadening thoracic cavity (Gans \& Clark 1978). This liver retraction mechanism - commonly called the "hepatic piston" - does not exist in birds and could represent a crocodylian apomorphy that evolved as part of a complex with other structural adaptations for aquatic life. On the other hand, if the hypothesis of Ruben et al. (1997) is correct, the hepatic piston mechanism would be a archosaurian synapomorphy that was secondarily lost in birds.

\section{Pulmonary cardiovascular considerations}

Gas exchange is expedited by a large surface area combined with a thin diffusion barrier, which separates oxygen-rich air from deoxygenated blood that enters the lungs from the right heart via the pulmonary artery. The connective tissue component of the air-blood barrier would be expected to be thin in a high-performance lung, because oxygen is very poorly soluble in collagen. Thus, collagen represents a formidable barrier to gas diffusion. The functional implication of these physical constraints is that effective gas exchange is not compatible with high pulmonary blood pressure because the latter will require thick, connective tissue-rich walls to prevent rupture of the capillaries. The same constraint does not apply to systemic capillaries. They are surrounded by incompressible tissue, which may have a hydrostatic pressure similar to that of the vascular bed. Pulmonary capillaries, on the other hand, are directly exposed to lung air, which during its inspiration has subatmospheric pressure. Accordingly, in snakes that have low blood pressure and engage in vertical movements, gas exchange tissue is found only in those parts of the lung directly adjacent to the heart (Lillywhite 1987). The caudal lung region is a sack, devoid of pulmonary vasculature. 


\section{The lungs of Brachiosaurus}

As an archosaur, Brachiosaurus presumably had multichambered lungs with an asymmetric (monopodial) branching pattern and tubular, arching chambers (Fig. 1). Extensive pneumatic spaces in all dorsal vertebrae as well as in the ribs demonstrate that the lungs were attached dorsally and laterally to the body wall. Similar spaces in the cervical vertebrae imply that the oesophagus was surrounded by air spaces, since the trachea must have lain ventral or lateral to the oesophagus and the pneumatic bones lie dorsal to it.

The extreme depth of the rib cage (the ribs are $2 \mathrm{~m}$ long!) implies that if the entry point of the vessels and airways (hilus) in the lung lay ventrally as in the crocodile, the pulmonary arterial blood pressure would have to exceed $200 \mathrm{~cm}$ $\mathrm{H}_{2} \mathrm{O}(147 \mathrm{~mm} \mathrm{Hg}$ ) in order to pump blood from the heart to the highest point of the lung. This pressure compares with $20-25 \mathrm{~mm} \mathrm{Hg}$ in the human lung (Penzlin 1996). In order to prevent rupture of the pulmonary capillaries, the walls would have to be reinforced with connective tissue, which would result in poor gas exchange conditions. Alternatively, the pulmonary vascular branching pattern could be characterized by large-bore arteries which open directly into a broad capillary bed. This system would provide an excellent pressure buffer but a low surface-tovolume ratio in the capillary bed. Such a condition is referred to as "high capillary loading," and in recent reptiles is indicative of animals which habitually breath-hold or have a low pulmonary ventilatory rate.

If the heart were located more dorsally, the pulmonary arterial pressure would decrease accordingly but the pulmonary venous pressure would increase, with even more drastic consequences for the pulmonary capillary bed. In man the pulmonary venous pressure is approximately $8 \mathrm{~mm} \mathrm{Hg}$, which allows blood to flow to a right ventricle or sinus venosus located $11 \mathrm{~cm}$ above the lung. In the lowest lung regions the venous pressure increases according to the hydrostatic pressure head. In Brachiosaurus pulmonary venous pressures in excess of $100 \mathrm{~mm} \mathrm{Hg}$ would result in pulmonary edema unless unknown mechanisms for decreasing the colloidal osmotic pressure of the lung tissue or increasing that of the blood are hypothesized. A more reasonable structural plan would place the hilus in the dorsal half of the lung, such that the pulmonary arterial blood pressure would not exceed $100 \mathrm{~mm}$ $\mathrm{Hg}$. If, as in monitor lizards and to some extent in crocodylians, the lungs are heterogeneously partitioned and the parenchyma is restricted to the dorsal half of the rib cage, pulmonary blood pressure values in Brachiosaurus are not likely to have exceeded those observed in mammals. It is possible that the cavernous, ventral portions of the lungs were entirely devoid of gas-exchange capillaries as in the snake lung, mentioned above (Lillywhite 1987).

The ventral portions of the lungs are thus postulated to be cavernous sacs that served for the storage and convection of gas. The large lung volume would result in a low total body density, thus reducing the weight on land.

A large lung volume would be advantageous in light of the extreme neck length in Brachiosaurus. Since the resistance to flow in tubular structures is inversely proportional to the fourth power of the diameter and is only directly proportional to the length, it is energetically advantageous to have a wide-bore trachea combined with a largevolume lung to reduce the deleterious effects of rebreathing a large tracheal volume.

Heterogeneous lung structure would also result in a low work of breathing. In mammals and in recent reptiles of similar lung structure, the compliance of the lung increases in direct proportion to the lung volume (Leith 1976, Perry and Duncker 1978): i.e., large lungs are easy to inflate. In terms of the energetics of breathing, less physical work is performed to move $1 \mathrm{ml}$ of air in a large lung than in a small one. In lungs of dissimilar structure, however, heterogeneous lungs have a greater compliance than do homogeneous ones. Thus, if Brachiosaurus had highly heterogeneous lungs its work of breathing could have been extremely low for two reasons: 1 ) because the lungs were very large and 2) because they were heterogeneous.

Arguments for the ancestral archosaurian hepatic piston notwithstanding, it is unlikely that such a mechanism existed in Brachiosaurus. The work required to move the liver and other abdominal viscera with each breath would have been enormous and the same end could have been reached by costal breathing, with the saclike regions of the lungs disposed laterally and ventrally beneath the ribs. A diaphragmaticus muscle, if present, could have served to stabilize the liver and to prevent its craniad movement during inspiration. Given the extreme weight of the rib cage it would possibly have been energetically advantageous to maintain a relatively low breathing frequency. Large, heterogeneous lungs are also consistent with this hypothesis. 


\section{Cross current gas exchange}

The avian lung is characterized by a highly efficient cross-current gas exchange model, which results in a $\mathrm{Po}_{2}$ value of expired gas that is less than that of the blood leaving the lung (Scheid \& Piiper 1970). Although there is no evidence that a large dinosaur maintained a high metabolic rate, it would certainly be of selective advantage to a large sauropod to possess an efficient respiratory system. If a large proportion of $\mathrm{O}_{2}$ can be extracted from the inspired air with each breath, fewer breaths are necessary and this results in conservation of metabolic energy. In addition, even a modest level of aerobic activity could result in problems with heat loss. The cross-current model may result in increased efficiency of heat loss and therefore could have been instrumental in the attainment of extreme body size in a subtropical environment.

\section{References}

Cuvier, G. 1812. Recherches sur les ossemens fossiles de quadrupèdes. Paris. 4to.

Duncker, H. R. 1978. Funktionsmorphologie des Atemapparates und Coelomgliederung bei Reptilien, Vögeln und Säugern. - Verhandlungen der Deutschen Zoologischen Gesellschaft 1978: 99-132.

Gans, C. \& Clark, B. 1976. Studies on Ventilation of Caiman crocodylus (Crocodilia: Reptilia). - Respiration Physiology 26: $285-301$
Janensch, W. 1937. Skelettrekonstruktion von Brachiosaurus brancai aus den Tendaguru-Schichten Deutsch-Ostafrikas. - Zeitschrift der Deutschen Geologischen Gesellschaft 89: $8 / 9$.

Leith, D. E. 1976. Comparative mammalian respiratory mechanics. - The Physiologist 19: 485-510.

Lillywhite, H. B. 1987. Circulatory adaptations of snakes to gravity. - American Zoologist 27: 81-95.

Penzlin, H. 1996. Lehrbuch der Tierphysiologie. 6. Auflage. Gustav Fischer Verlag, Jena Stuttgart. p.280.

Perry, S. F. 1983. Reptilian lungs. Functional anatomy and evolution. 81 pp., Advances in Anatomy Embryology and Cell Biology. Springer Verlag Berlin Heidelberg New York.

- 1992. Gas exchange strategies in reptiles and the origin of the avian lung. In Wood, S. C., Weber, R. E., Hargens, A. R. \& Millard, R. W. (eds.) Physiological Adaptations in Vertebrates. Respiration, Circulation, and Metabolism. Marcel Dekker, New York, Basel, Hong Kong. pp. 149-167.

Perry, S. F. \& Duncker, H. R. 1978. Lung architecture, volume and static mechanics in five species of lizards. Respiration Physiology 34: 61-81.

Ruben, J. A., Jones, T. D., Geist, N. R \& Hillenius, W. J. 1997. Lung structure and ventilation in theropod dinosaurs and early birds. - Science 278: $1267-1270$.

Ruben, J. A., Dalsasso, C., Geist, N. R., Hillenius, W. J., Jones, T. D. \& Signore, M. 1999. Pulmonary function and metabolic physiology of theropod dinosaurs. - Science 283: $514-516$.

Sasso, C. D. \& Signore, M. 1998. Exceptional soft-tissue preservation in a theropod dinosaur from Italy. - Nature 392: 383-387.

Scheid, P. \& Piiper, J. 1970. Analysis of gas exchanges in the avian lung: Theory and experiments in the domestic fowl. - Respiration Physiology 1970(9): 246-262.

Thomason, J. J. 1995. Functional Morphology in Vertebrate Paleontology. 293 pp. Cambridge University Press, Cambridge.

Weishampel, D. B., Dodson, P. \& Osmolska, H. 1990. The Dinosauria. 733 pp. University of California Press, Berkley, Los Angeles, London. 